\title{
Ovarian hyperstimulation syndrome mimicking ovarian malignancy: a case report
}

\author{
Sujata Singh, Sasmita Swain, Lucy Das, Om Avishek Das, Balaram Sahoo*, Sasmita Sahoo
}

Department of Obstetrics \& Gynaecology, SCB Medical College, Cuttack, Odisha, India

Received: 25 September 2015

Accepted: 02 November 2015

\section{*Correspondence:}

Dr. Balaram Sahoo,

E-mail: drbalaramsahoo1977@gmail.com

Copyright: @ the author(s), publisher and licensee Medip Academy. This is an open-access article distributed under the terms of the Creative Commons Attribution Non-Commercial License, which permits unrestricted non-commercial use, distribution, and reproduction in any medium, provided the original work is properly cited.

\section{ABSTRACT}

Ovarian hyperstimulation syndrome (OHSS) is an iatrogenic complication. In most cases, the clinical manifestations of OHSS are self-limited and OHSS resolves spontaneously within a few days, provided that appropriate supportive measures are taken. However, OHSS has been associated with substantial morbidity, principally acute respiratory distress, and fatal complications have been reported in patients with severe or critical OHSS.

Keywords: Ovarian hyperstimulation syndrome, Ascites, Ovarian cyst

\section{INTRODUCTION}

Ovarian hyperstimulation syndrome (OHSS) is an iatrogenic complication that occurs in the luteal phase of an induced hormonal cycle. ${ }^{1}$ The pathogenesis of OHSS involves the effect of vasoactive substances that are secreted upon ovarian stimulation and cause increased vascular permeability with depletion of intravascular volume and massive extravasation of protein-rich fluid into the peritoneal space, the pleural space, and, less commonly the pericardial space, the pleural space and less. $^{2-3}$

\section{CASE REPORT}

A 25-year nullipara presented to OPD with complaints of abdominal pain, distension and vomiting with diarrhea for 6 days followed by dyspnea for 3 days, which was slow in onset and gradually progressing. Her ascitic fluid tapping was done in a local hospital but as her symptoms did not subside she was referred to our tertiary centre. She had history of $5 \mathrm{yrs}$ of primary infertility and was on treatment with Tab Myoinositol for last 2 months, her menstrual cycles were regular. In her present cycle she was given Inj hMG 150IU on D3, D5, D7, D9, D11, D13, on D15 ultrasound revealed follicles of size $30 \mathrm{~mm}$ and on same day Inj hCG 10000 IU was given. Intrauterine insemination was done on D16 and Inj hCG 10000 IU was repeated on D19 \& D21. On examination she was conscious, oriented, afebrile, pale and ill looking, weight: $78 \mathrm{~kg}$ BMI 25.4, pulse: 110/min and regular, blood pressure: $110 / 70 \mathrm{mmHg}$, respiratory rate being $24 / \mathrm{min}$. Bilateral pitting pedal oedema present. Abdomen was distended with generalized tenderness and abdominal girth measured $97 \mathrm{~cm}$ with tense ascites and fluid thrill, there was no organomegaly. Pelvic examination revealed congested cervix, uterus and ovaries could not be palpated because of tense ascites, fornices were full. Chest examination suggested signs of bilateral pleural effusion as evidenced by decreased breath sounds and dullness in both lower lung fields.

On investigating, patient had $\mathrm{Hb}-12 \mathrm{gm} / \mathrm{dL}$, Hct $36 \%$, leucocytosis (TLC $10.2 \times 10^{3} / \mathrm{L}$ ) with predominant polymorphs. Coagulation profile revealed normal platelets count, PT $14.8 \mathrm{sec}$, aPTT $28.8 \mathrm{sec}$, INR 1.24. LFT and RFT revealed marginally elevated liver enzymes and increased serum urea, creatinine (S. Bilirubin total $1.1 \mathrm{mg} \%$, direct $0.4 \mathrm{mg} \%$, SGOT $142 \mathrm{IU} / \mathrm{L}$, SGPT 158 IU/L, S. Alkaline phosphate $238 \mathrm{IU} / \mathrm{L}, \mathrm{S}$. urea $54 \mathrm{mg} \%$, 
S. creatinine $1.6 \mathrm{mg} \%)$ with hyponatraemia and hypoalbuminemia (Serum Na 125 meq/L, Serum K 4.2 meq/L, Serum protein $4.7 \mathrm{gm} \%$, Serum Albumin 2.1 gm\%) and normal blood sugar level. Chest $\mathrm{X}$ ray revealed bilateral minimal pleural effusion and ascitic fluid cytology revealed no malignant cells with increased sugar and protein. USG revealed bilateral enlarged ovaries with multiple follicular cysts with gross ascitis. (Rt ovary $7.85 \times 4.43 \times 8.25 \mathrm{~cm}, 10-12$ follicles largest one being $42 \times 40 \mathrm{~mm}$ and Lt ovary $7.28 \times 4.36 \times 5.35 \mathrm{~cm}, 9-10$ follicles largest one being $32 \times 28 \mathrm{~mm}$ ), serum estradiol $6258.52 \mathrm{pg} / \mathrm{ml}, \mathrm{CA}-1251349 \mathrm{U} / \mathrm{ml}$.

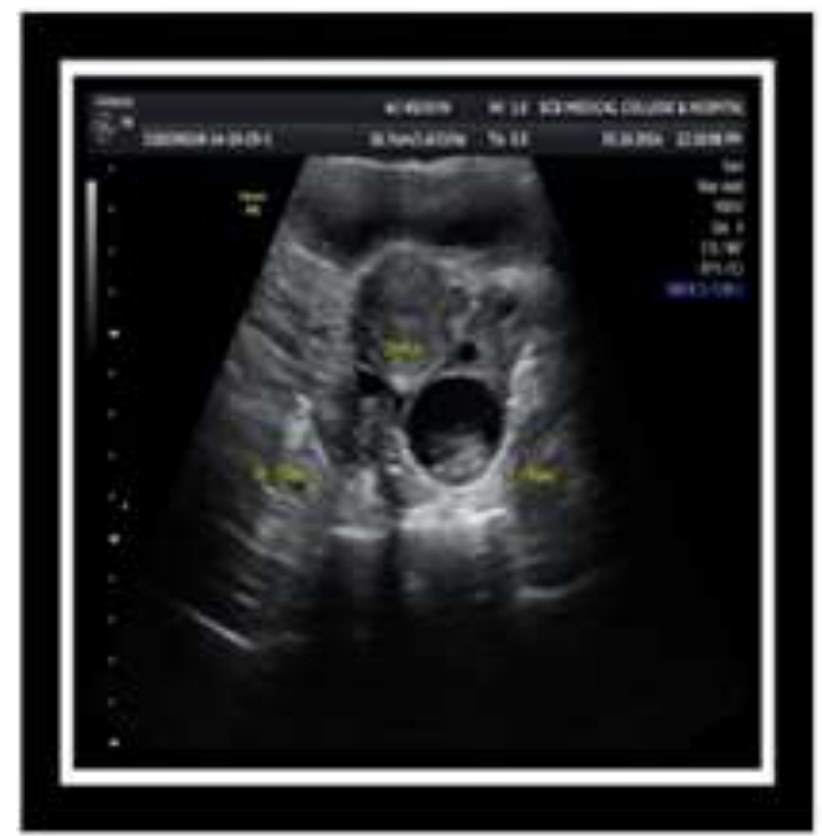

Figure 1: Ultrasound picture of right ovary at admission.

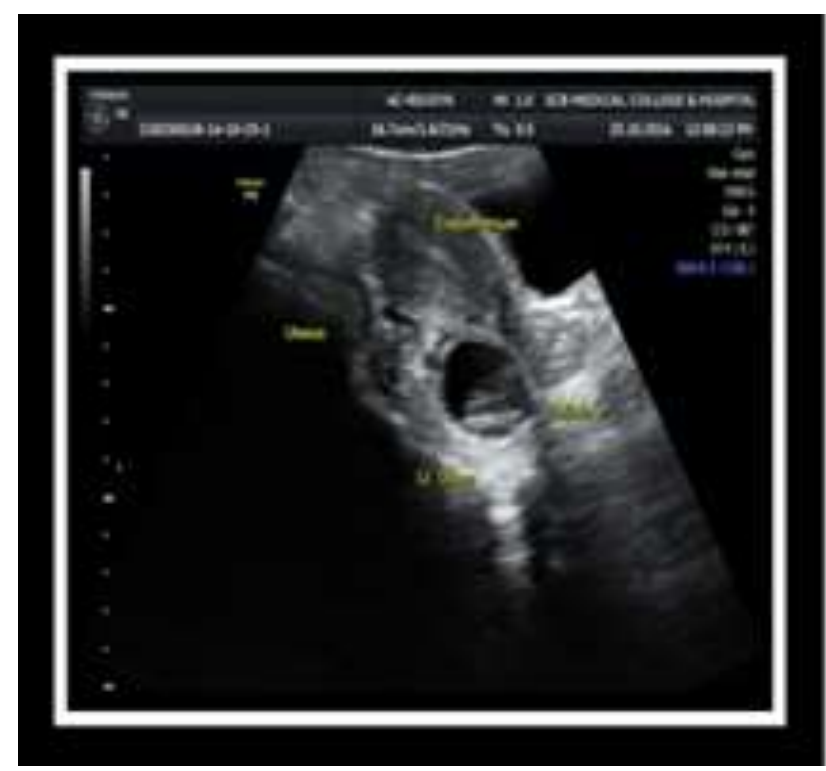

Figure 2: Ultrasound picture of left ovary at admission.

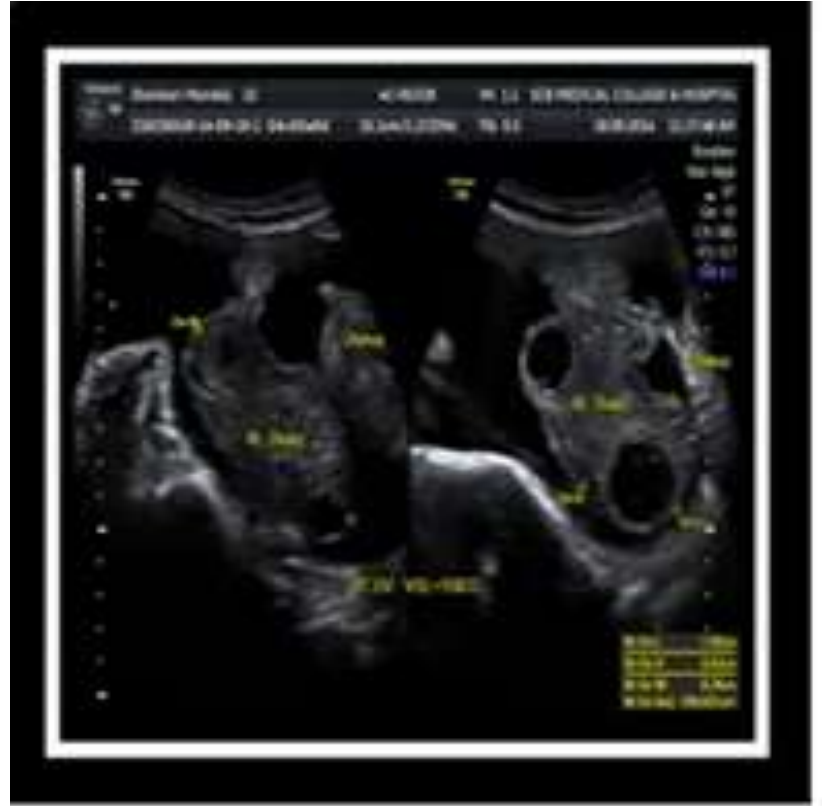

Figure 3: Ultrasound picture of right ovary at discharge.

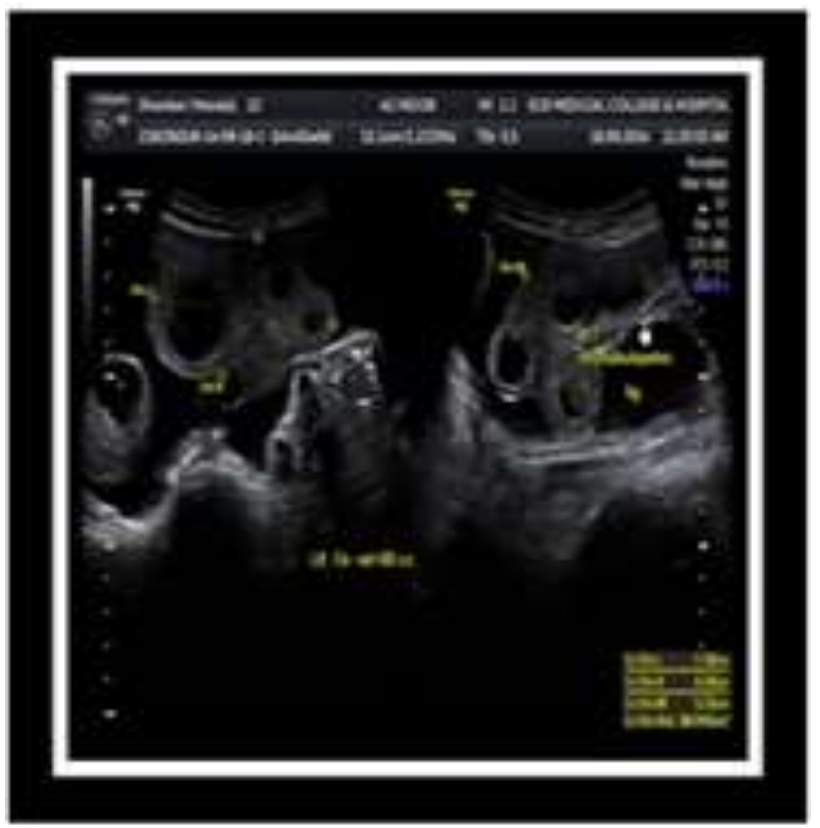

Figure 4: Ultrasound picture of left ovary at discharge.

After investigations she was diagnosed as a case of Severe Ovarian Hyperstimulation Syndrome (Grade-VI OHSS). She was managed by oxygen inhalation, saline infusion, kept nil per oral and electrolyte imbalance was corrected with $3 \% \mathrm{NS}$ admission, for respiratory distress nebulisation with Levosalbutamol and Fluticasone, Inj Deriphylline was given, Albumin infusion once daily alternate days was given for correction of hypoproteinemia, for altered liver function Tab Silymarin and Ursodeoxycholic was prescribed. After correction of hypovolemia Inj Furosemide 1 ap iv bd was given for 5 
days, tab cabergoline $0.5 \mathrm{mg}$ twice daily was given to decrease vascular permeability. Her management was carefully tailored by monitoring body weight, abdominal circumference, input/output, serum electrolytes, ultrasonography, and renal functions on regular basis. Later ultrasound-guided abdominal paracentesis was performed 3 times, in view of respiratory distress and increasing abdominal girth. With this management protocol patient's general condition improved as well as biochemical parameters normalized and reduction in follicle size was confirmed by ultrasound.

\section{DISCUSSION}

Medical management is mainly to maintain circulatory function and prevent organ dysfunction. The intravascular volume should be maintained to prevent hemoconcentration and allow sufficient urine output. Initial fluid of choice is crystalloids. In patients with hematocrit more than $45 \%$ or hypoalbuminemia less than $30 \mathrm{gm} / \mathrm{L}$ or ascites, human albumin is the plasma expander of choice. Once sufficient volume expansion has been achieved and the hematocrit is less than $36 \%$ frusemide should be given to assess the renal function. In patients with hydrothorax who are not symptomatic, conservative management is sufficient. If patient has respiratory symptoms thoracocentes is should be done. If ARDS develops patient should be ventilated with low tidal volume $(6 \mathrm{ml} / \mathrm{kg}$ body weight $)$ and plateau pressure less than $30 \mathrm{~cm}$ of water. Patient should be investigated for evidence of infection. Use of steroids in ARDS is not recommended at present. $^{5}$ In severe cases of OHSS prophylactic anticoagulation should be used. In presence of thromboembolism therapeutic anticoagulation is indicated. ${ }^{6}$

\section{Funding: No funding sources Conflict of interest: None declared Ethical approval: Not Required}

\section{REFERENCES}

1. Wood N, Edozien L, Lieberman B. Symptomatic unilateral pleural effusion as a presentation of ovarian hyperstimulation syndrome. Hum Reprod. 1998;13(3):571-2.

2. Abramov Y, Elchalal U, Schenker JG. Pulmonary manifestations of severe ovarian hyperstimulation syndrome: a multicenter study. Fertil Steril. 1999;71(4):645-51.

3. Murray A, Rombauts L. Unilateral pleural effusion as the main presentation of "early onset" severe ovarian hyperstimulation syndrome. Fertil Steril. 2004;81(4):1127-9.

4. Whelan JG 3 rd, Vlahos NF. The ovarian hyperstimulation syndrome. Fertil Steril 2000;73:883-96.

5. Ware LB, Matthay MA. The acute respiratory distress syndrome. N Engl J Med. 2000;342:1334-49.

6. Delvigne A, Rozenberg S. Review of clinical course and treatment of ovarian hyperstimulation syndrome (OHSS). Hum Reprod Update. 2003;9(1):77-96.

Cite this article as: Singh S, Swain S, Das L, Das OA, Sahoo B, Sahoo S. Ovarian hyperstimulation syndrome mimicking ovarian malignancy: a case report. Int J Reprod Contracept Obstet Gynecol 2015;4:2088-90. 